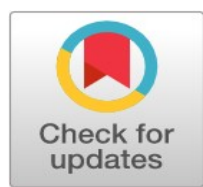

\title{
The effects of high performance work system on employee attitudes: A study of international organization
}

\author{
Yousif El-Ghalayini * \\ Australian College of Kuwait City, Kuwait
}

\author{
Index Terms \\ High performance \\ Work system \\ Employee attitudes \\ International organization
}

Received: 12 May 2016

Accepted: 21 August 2016

Published: 27 October 2016

\begin{abstract}
Although there is a growing body of evidence demonstrating the effects of HPWS on organizational performance, there is less evidence evaluating the effects of adopting HPWS in international organizations, particularly Intergovernmental organizations (IGO). IGOs, such as United Nations (UN), World Bank (WB), and International Monetary Fund (IMF), are international bodies that serve different mandates and aim at maintaining global socioeconomic stability between member states' governments. Despite the increasing interest among IGOs' managers in adopting HPWS, research in this unique organizational context lags behind, revealing a significant gap in HRM literature. This mixed methods research study seeks to address this gap by reporting the results of a staff survey and follow-up interviews conducted on a cross-section of one of the largest IGOs in the region. The results have shown different effects of the bundles of HPWS practices on organizational performance. The results are discussed in light of HRM theory to explore the importance of organizational context on the link between human resource management and organizational performance. The results raise issues about the universal applicability of HRM-performance research and have implications for the standardization of HRM policies and practices within the intergovernmental organization.
\end{abstract}

(C) 2016 The Author(s). Published by TAF Publishing.

\section{INTRODUCTION}

In the last three decades, a growing body of research has suggested that using a mix or system of human resources management practices would lead to superior organizational performance (Datta, Guthrie \& Wright, 2005; Zhang, Zhu, Dowling \& Bartram, 2013). These practices (such as selective recruitment and hiring procedures, performancebased compensation systems, employee participation, and training and development) have been referred to as (HPWS) and originated from the study of strategic human resource management (SHRM), where researchers have examined the effects of adopting HPWS on organizational performance (Appelbaum, Bailey, Berg \& Kalleberg, 2000; Boxall, Ang \& Bartram, 2011). Much of this research has shown a positive link between adopting HPWS practices and organizational performance (Mahdi, Liao, Muhammad \& Nader, 2014; Macky \& Boxall, 2007; Datta et al., 2005; Guest, 2002). However, most empirical analysis applied by researchers addressing the HPWS-performance relationship has been based on a narrow view of performance

\footnotetext{
* Corresponding author: Yousif El-Ghalayini

†Email: y.ghalayini@ack.edu.kw
} 
measurement, focusing primarily on financial indicators within private sector (Cafferkey \& Dundon, 2015; Kalleberg, Marsden, Reynolds \& Knoke, 2006). Although many scholars have referred to worker attitudes as the intermediate variable between HPWS practices and organizational performance, current research provides no insight into the impacts of HPWS on individual worker attitudes (GouldWilliams, 2004). As such, there is very little evidence concerning the effects of HPWS in other organizational contexts and whether these practices lead to desirable individual outcomes. It is the aim of this paper to provide such evidence from intergovernmental organization (IGO).

IGOs, such as United Nations (UN), World Bank (WB), and International Monetary Fund (IMF), are multilateral institutions serving different mandates and aim at maintaining global socioeconomic stability between member states' governments. As public service providers, IGOs operate across national boundaries, hire expatriates, deal with cultural diversity, and rely on donations from the governments of member states to fund their programs. This paper seeks to examine the effects of adopting HPWS practices in this unique organizational context using data from staffsurvey and follow-up interviews from cross section of one of the largest UN headquarters. The first part of the paper provides an overview of the main theoretical and methodological issues within existing HPWS research. Then a description is provided of the research context and methodology used to collect data and test the research hypotheses. The results of statistical analysis are provided along with summaries of interview statements collected from interviews with randomly selected IGO workers. Finally, the concluding section highlights the implications of the research findings with reference to the extent to which HPWS practices lead to positive worker attitudes and recommendation to IGOs' managers.

\section{LITERAT URE REVIEW}

\section{What is High Performance Work System}

Within management literature, the basic thesis underlying the majority of HRM studies is that people are the most valuable asset that organizations can develop to achieve and sustain high levels of organizational performance (Becker \& Huselid, 2006; Sourchi \& Liao, 2015. Due to the increasing interest within management studies in HRM practices, a new notion of "best practices" has emerged. Sometimes this is referred to as "high-performance work systems" (Appelbaum et al., 2000), "high commitment" HRM (Guest 2001, 2002), or "high involvement" HRM (Wood, 1999). High- performance work systems (HPWSs) are conceptualized as a set of distinct but interrelated HRM practices with a particular configuration, or architecture, designed to optimize organizational performance through promoting employee skills development, work reorganization, and enhanced worker attitudes (Beaupré \& Cloutier, 2007; Guthrie, 2001; Ingvaldsen, Johansen \& Aarlott, 2014). The key idea is that there is a synergistic effect with a cluster of HRM practices, with the potential to bring about improved organizational performance through providing more flexibility of work structures, extensive worker participation, and more cooperative relationships between managers and employees (Appelbaum et al., 2000). Accordingly, HPWS represents a combination of several HRM practices into a bundle that has systematic and synergistic effects aimed at selecting, developing, retaining, and motivating employees with better abilities in work-related activities, leading to improved organizational performance (Boxall, 2012).

This new concept of managerial focus that embraces people management through HPWS, can be traced back to Huselid (1995) seminal work, The Impact of Human Resource Management Practices on Turnover, Productivity, and Corporate Financial Performance. In this work, Huselid (1995) surveyed senior human resource professionals in 968 publicly held organizations in the US. His findings show a positive correlation between HPWS and the economic profit per employee. Since then, the topic became very popular and an abundance of research attempted to replicate Huselid (1995) findings on the relationship between deploying HPWS in the workplace and organizational performance. The HRM-Performance relationship has been researched from different perspectives rooted in organizational behaviour, sociology, economics, industrial relations, and organizational psychology, with a particular emphasis on the impact of various combinations of HPWS practices on a range of performance outcomes, such as employee skills, behaviours, and attitudes (Paauwe, 2009). For instance, MacDuffie (1995) proposed one of the earliest and most comprehensive studies on HPWS. He argued that HPWS practices affect performance not individually but as interrelated elements in an internally consistent "bundle" or "system" that "shapes the pattern of interactions between and among managers and employees" (p. 200). In a similar study, Appelbaum et al., (2000) and her colleagues investigated the effects of HPWSs on organizational performance in the US steel, apparel, and medical imaging industries. The authors reported that adopting HPWS has positive effects on employee measures of trust, organizational com- 
mitment, job satisfaction, and lower job stress. Furthermore, empirical evidence supporting these views on HPWS has emerged in other organizational contexts. For instance, in a recent empirical study on MNEs operating in Russia, the US, and Finland, Fey, Björkman \& Pavlovskaya (2000) examined the HPWS-performance linkage to understand how contextual factors may affect this relationship. The authors' findings have shown that the contextual factors led to mixed HRM outcomes due to variations in national culture, market, and competitive context. For instance, training was more important and motivating in Russia, a country that shifted from communism to a market economy, where many people were trained in areas not related to their current job. This raises one of the key discussions within HRM literature examining whether HPWSs are universally applicable or may not be optimal in different settings (Sackmann, Phillips, Kleinberg \& Boyacigiller, 1997).

\section{Limitations, Contradictions and Inconsistencies}

Despite the substantial research on HPWS and the growing empirical data on its link to organizational performance, there are some real criticisms of this approach to HRM. A brief overview of HRM literature demonstrates conflicting views on major issues related to HPWS. Some scholars questioned whether these systems actually work and if so, how they lead to enhanced organizational performance (Boselie, Dietz \& Boon, 2005; Guest, 2001). Another criticism of HPWS is whether these practices have negative effects on employees, such as job stress and work intensification (Stanton \& Manning, 2013; Macky \& Boxall, 2007). For instance, there is no agreement among HRM scholars on the precise mix of HRM practices that constitute HPWS. Boselie et al., (2005;72), in their article entitled "Commonalities and contradictions in HRM and performance research," analyzed 104 articles addressing HPWS that have been published over a decade. They argue that "no consensus has emerged on what employee management activities should be in a comprehensive HRM checklist". Studies defined different bundles of HPWS practices without an agreement on a coherent and fixed list of practices that constitute HPWS (Boselie et al., 2005). Many scholars have been attempting to explain the contradictions and inconsistencies on the structure of HPWS within HRM-performance literature, proposing different methodological and theoretical concerns. Gould-Williams (2004:66), in his empirical analysis of HPWS in public sector organizations, attempted to summarize major reasons that explain these differences by highlighting some of the main problems in HRM research, arguing that In part this reflects the eclectic approach taken by researchers in evaluating the effects of a range of HRM practices... the research to date is limited in several ways. First, early studies adopted a very narrow view of performance, focusing primarily on financial indicators. Second, the research evidence is based on views of single organizational representatives, namely senior persons who are more likely to provide biased reports of the extent and effects of HRM practices. Third, although several studies have sought to use a variety of performance outcomes, such as productivity and financial measures, few have considered the effects of HRM practices on workers.

Therefore, HPWSs are broadly defined and no specific list of practices constitutes these systems. However, close reading of the HRM literature indicates that the most acceptable and widely used bundles of HPWS practices are proposed by Boselie et al., (2005:73). In their study, the authors reviewed every empirical research article into the linkages between HPWS practices and performance published for a decade. They conclude that the top four HRM practices in the HPWS list have been training and development, contingent pay and reward schemes, performance management and appraisal, and recruitment and selection processes. The authors justify their findings claiming that these practices reflect the main functions of HRM, "namely to identify and recruit strong performers, provide them with the abilities and confidence to work effectively, monitor their progress towards the required performance targets, and reward them well for meeting or exceeding them".

Furthermore, current research provides no insight into the impacts of HPWS on individual worker attitudes (GouldWilliams, 2004). The majority of research examining the implications of adopting HPWS on organizational performance originates in American and European private sector firms utilizing financial outcomes as the only indicator of organizational performance. There is very little evidence concerning the impacts of HPWS on individual worker attitudes, which makes it unclear whether these practices lead to desirable individual outcomes.Finally, the majority of research addressing the relationship between organizational performance and HPWS practices has been tested in private sector organizations, with only minimal research evaluating the effects of these systems in different organizational contexts. Despite the substantial empirical evidence that HPWS practices are positively related to organizational performance in the private sector, there is a great need to investigate this relationship in other organizational contexts (Katou \& Budhwar, 2007). Only recently, scholars began 
considering the context as an important contingency factor, arguing that understanding the effects of HPWS practices in different organizational settings is essential to the theoretical development of the field of HRM (Teo \& Crawford, 2005; Skaggs \& Youndt, 2004; Daley \& Vasu, 2005). HRM researchers began investigating the distinctions between different organizations, such as manufacturing and service organizations, public, non-profit, and private organizations, examining the effects of the organizational context on HRM outcomes.

In summary, the researches addressing HPWS have few limitations. First, it is still unclear whether HPWSs are universally applicable on one hand, and what specifically constitutes this specific list of HRM practices on the other hand. Second, most empirical analysis applied by researchers addressing the HPWS-performance relationship has been based on a narrow view of performance measurement, focusing primarily on financial indicators (Kalleberg et al., 2006). Although many scholars have referred to worker attitudes as the intermediate variable between HPWS practices and organizational performance, current research provides no insight into the impacts of HPWS on individual worker attitudes (Gould-Williams, 2004). Finally, the majority of research addressing the relationship between organizational performance and HPWS practices focuses on private sector organizations, with only minimal research evaluating the effects of these systems in different organizational contexts. Therefore, there is very little evidence concerning the impacts of HPWS in public organizations and particularly IGOs.

\section{HRM in Public Sector Organizations}

The literature on HRM has focused on private sector organizations and there has been very limited research on public sector organizations. Despite the substantial differences between public and private organizations, there is no clear distinction within HRM literature addressing how these differences may impact the practice of HRM in these different work environments (Beadles, Aston, Lowery \& Johns, 2015; Mostafa \& Gould-Williams, 2014; Rainey \& Bozeman, 2000). Some scholars stated that HRM literature "disregards or gives only some acknowledgement of HRM within the public sector, relying instead on appropriating a business model of firms as the general context for HRM scholarship" (Brown, 2004:305). Others disagree, arguing that the "available evidence does not provide clear support for the view that public and private management are fundamentally dissimilar in all important respects" (Boyne
2002:118). Therefore, contemporary HRM research does not clearly indicate significant differences between private and public organizations but rather "disregard [s] or give [s] only cursory acknowledgement" of HRM within the public sector (Brown, 2004:304). However, the agreement among scholars is that the adoption of New Public Management (NPM) has resulted in a dramatic change in HRM within public sector organizations. The introduction of NPM has resulted in a strategic approach to HRM within the public sector. Several authors have argued that within the traditional model of public administration, personnel management was subject to bureaucratization under which all activities were formalized by predefined, systemized rules and procedures, and was characterized by rational-legal bureaucracy based on specialization, prevention of arbitrary dismissal, reliance on authority of work position, and merit selection (Schroeder, 1992). For instance, within that old system, staffing and recruitment were centralized and employment based on the notion of lifelong employment with narrow, specific, task-based and highly routinized jobs and strict seniority based on length of service (Brown, 2004). The changing structure and operations of governments, paralleled with the adoption of NPM, have replaced this traditional Weberian model of centralized and bureaucratic practices with private-sector HRM systems (Colley, McCourt, \& Waterhouse, 2012). However, there were no clear distinctions between the adoption of HPWS in public and private organizations.

Gould-Williams (2004) in his study examining the effects of HPWS practices on public sector employees in the Government of Wales found that some specific HRM practices might have different outcomes within public organizations. For instance, results have shown that training provisions had the most significant and positive effects on employee commitment and job satisfaction in public sector organizations. However, the effects of other HPWS practices were similar across public and private-sector organizations. Similarly, Leggat, Bartram \& Stanton (2011) in their study on public health organizations in Australia, reported a positive correlation between certain aspects of HPWS practices and improved care delivery and patient outcome. Their findings reported a significant gap between HPWS policies and actual practices. They reported that public healthcare organizations in Australia generally do not have the necessary aspects of HPWS in place, which necessitates more effective implementation for the newly adopted policies.

Beaupré \& Cloutier (2007) conducted one of the first stud- 
ies of its kind to examine the adoption of HPWS in the public service sector, highlighting the uniqueness of public sector organizations, where performance outcome is not linked to financial indicators but rather to political costs. The study was an exploratory examination of the managerial reform within the Government of Quebec in 1999, and the effects of creating Autonomous Service Units (ASUs) within the government body. In their study, the main objectives were to verify if the new management model of Autonomous Service Units corresponded to a "high-performance" management model, and to examine the effects of establishing these ASUs in several government departments. The authors were able to organize group discussions and semistructured interviews with personnel from four different government departments. In their findings, the authors reported that "results show that two of the four ASUs under study have the characteristics of a 'high-performance' management model: the employees are committed and motivated, their level of satisfaction is very high ... and the economic performance of the ASU showed exceptional growth". Therefore, it appears that the public sector managers are attempting to transfer HPWS practices to public organizations. However, further research is needed to examine HPWS practices in specific types of public sector organizations such as IGOs, to assess the effects of these practices on workers. This analysis would contribute to further understand the desirability among IGOs' workers of adopting HPWS practices.

\section{Research Hypotheses}

Drawing from normative HRM theories, positing that HRM practices lead to enhanced employee attitudinal outcomes, such as improving employee motivation, commitment, and satisfaction, this study hypothesizes that organizational HPWSs would develop employee attitudes. Consistent with HRM theory: key individual worker attitudes satisfaction, motivation, commitment, and intention to quit are the determinants of the effects of HPWS. HPWS practices are defined as IGO activities related to staffing and recruitment, performance appraisal, compensation and rewards, and training and development. In this research, we set out to test the effect of HPWS on four key attitudinal measures: motivation, commitment, satisfaction, and intention to quit. These four measures are used as the dependent variables and determinants of the effects of HPWS. As such, the following hypotheses have been identified:

HI: There are positive effects of HPWS practices on employee commitment.
H2: There are positive effects of HPWS practices on employee job satisfaction.

H3: There are positive effects of HPWS practices on employee motivation.

H4: There are inverse effects of HPWS practices on employee intention to quit.

\section{RESEARCH METHODOLOGY}

\section{Research Context}

The research setting for this study is the United Nations Relief and Works Agency (UNRWA). The UNRWA is an international relief and human development Agency with a quasigovernmental role, delivering essential public services to over five million registered refugees. UNRWA services include education, health care, social services, and emergency aid. In 2006, the UNRWA began a comprehensive reform program to strengthen its management capacity. Accordingly, one of the main achievements of the reform process is the deployment of new HRM systems that included recruitment strategies, performance management systems, training and development, and reward and recognition systems. The underlying message of the reform process has been adopting HPWS practices, which is the object of this study (UNRWA, 2006a).

The Agency drafted a "Mid-Term Plan" (MTP) for the reform process with an emphasis on HRM as the main area of organizational change. According to the UNRWA's MTP: The Agency's workforce is its most valuable asset. Over recent years, insufficient attention to staff training and development has been a factor in the deterioration of service standards across the Agency. From this standpoint, renewed investment in building the capacity of UNRWA's human resources is an independently worthy objective as well as a vital means by which strategic objectives can be realized investing in staff capacity will ultimately benefit the Palestinian community, while also contributing to the quality and impact of the Agency's interventions. For these reasons, the MTP incorporates multi-faceted capacity-building components, embracing human resource and career development needs, managing information skills and enhancing capacity for research and analysis. These components could form the basis for a more comprehensive strategy for staff development (UNRWA, 2006b:5).The Agency, in furtherance of the MTP, established a Human Resources Task Force (HRTF) with the goal of drafting a Human Resources Management Strategy for the Agency. The HRTF was established for consultation to elicit a range of views from within the Agency. The HRTF was guided by external consultants 
and advised by a technical team of internal specialists on HRM processes. Thus, the main task of the HRTF team was to conduct a comprehensive review of HRM policies and processes and identify any inefficiency in the old system. This review was the first step towards creating a new HRM system to deliver better human resourced programs, which appeared to be adopting high-performance work systems (UNRWA, 2006b).

\section{Data Collection}

To collect data, surveys were distributed and interviews were conducted with program administrators, operations' directors, and field staff representing employees from different countries with varying lengths of service as well as an extensive range of levels of education and professional backgrounds.

A total of 505 questionnaires were distributed in seven service departments. Over a period of six weeks, respondents returned their completed questionnaires directly to the researcher by hand. A total of 234 usable responses were obtained providing a response rate of 46.3 per cent. In addition to questionnaires, a total of 10 face-to-face interviews were conducted to better understand the data obtained from questionnaires. These individual interviews were conducted with the person responsible for human resources in addition to line managers and staff members. The duration of each interview was between 30 and 120 minutes.

\section{Sample}

The sample of 234 employees had the following characteristics: 67.8 per cent male; 15.3 per cent were between the ages of 18-30 years, 49.3 per cent between $31-45$ years, 35.0 per cent between $46-60$ years and 0.5 per cent were over 60 years. The average length of service was 13.08 years (standard deviation 7.92). For qualifications, 20.5 per cent had diploma, 47.3 per cent had a university degree, 21.8 per cent had postgraduate university degree, and 10.5 per cent had no formal qualifications. Participants' positions varied as 61.4 per cent were frontline workers, 25.7 per cent supervisors, 12.4 per cent middle managers, and 0.5 per cent program managers.

The sample were based in the following departments: Engineering, Infrastructure and Camp Development 21.0 per cent; Education 29.0 per cent; Microfinance 10.0 per cent; Procurement 8.0 per cent; Financial Services 3.0 per cent; Human Resources and Administration 8.0 per cent; Job Creation Program 5.0 per cent; Logistics and Support
Services 5.0 per cent; Community Services and Mental Health 2.0 per cent; Health 1.0 per cent.

\section{Measures}

There are four independent variables and four dependent variables for this study related to the four research hypotheses. The four independent variables are the measures of the bundles of HPWS practices: staffing and recruitment, performance appraisal, compensation and rewards, and training and development. In order to measure these variables, the HRM Practices and Policies Profile (HRMPPP) questionnaire was used to investigate individual perceptions of HRM practices. The questionnaire is based upon the typology of HRM practices proposed by Schuler \& Jackson (1987) and their empirical work in the U.S (Sparrow $\& \mathrm{Wu}, 1998$ ). The items are presented as 23 pairs of selfexplanatory alternative HRM practices representing four bundles of HPWS practices. Each bundle evaluates one major HRM function and participants were told that there are no right or wrong answers, and they should indicate their choice by choosing an appropriate number (ranged from 1 to 7) from the pairs of HRM choices. Higher score indicates the extent to which the organization uses specific HPWS practice across the whole sample which identifies the main characteristics of the current HRM system.

The four dependent variables are employee commitment, satisfaction, motivation and intention to quit. A set of questionnaires grouped in one single questionnaire was used to measure these variables. Organizational commitment was measured based on fifteen items using Porter, Steers, Mowday \& Boulian (1974) Organizational Commitment Questionnaire (OCQ). Job Satisfaction was measured based on the Job Satisfaction Survey (JSS) (Spector, 1997) which is a 36-item questionnaire that uses nine facet scales to assess employee attitudes about the job and aspects of the job and the organization. Finally, Lindner (1998) organizational motivation questionnaire was used to define the degree of motivation within the work place using the main ten employee motivating factors. The questionnaire was first used in a study at The Ohio State University's Piketon Research and Extension Center. The mean of the perception scores for each of the items was calculated to give an overall attitude score. For Intention to quit: single item measure was used for employees' 'intention to leave the organization'. Respondents were asked to indicate the degree to which they agreed with the statements: 'I intend to leave this organization'. Surveys are in the public domain and no permission is required for its use. 


\section{RESULT S AND DISCUSSION}

Table 1, below, provides the means, and standard deviations based on a 7-point scale for the 23 items used as measures of bundles of HPWS practices. The findings suggest that there was an uptake of three HPWS practices. For the staffing and recruitment bundle, the results suggest that the organization relies heavily on internal resources, uses fixed and explicit job description, and an extensive socialization process for new hires.

However, there are limitations on the opportunities for advancement within the organization. These limitations may be referred to the narrow career path for advancement which is limited to specific area of practice or the same business unit. For performance appraisal HPWS practices, findings show that the performance appraisal process focuses on results, which is crucial for the appraisal process; other aspects of the HPWS are not fully adopted by the Agency. For instance, results indicate that there is little attention to employee development.

Previous research emphasized that the appraisal process should capture areas for employee development based on employee engagement and focus on group performance (Payne, Horner, Boswell, Schroeder \& Stine-Cheyne, 2009). Finally, results indicate that employees are neutral and have mixed perceptions with regards to the performance appraisal time frame whether it focused on long or short term criteria. As shown above, there was a little uptake of many HPWS practices especially in the area of compensation and rewards.

TABLE 1. Means and standard deviations

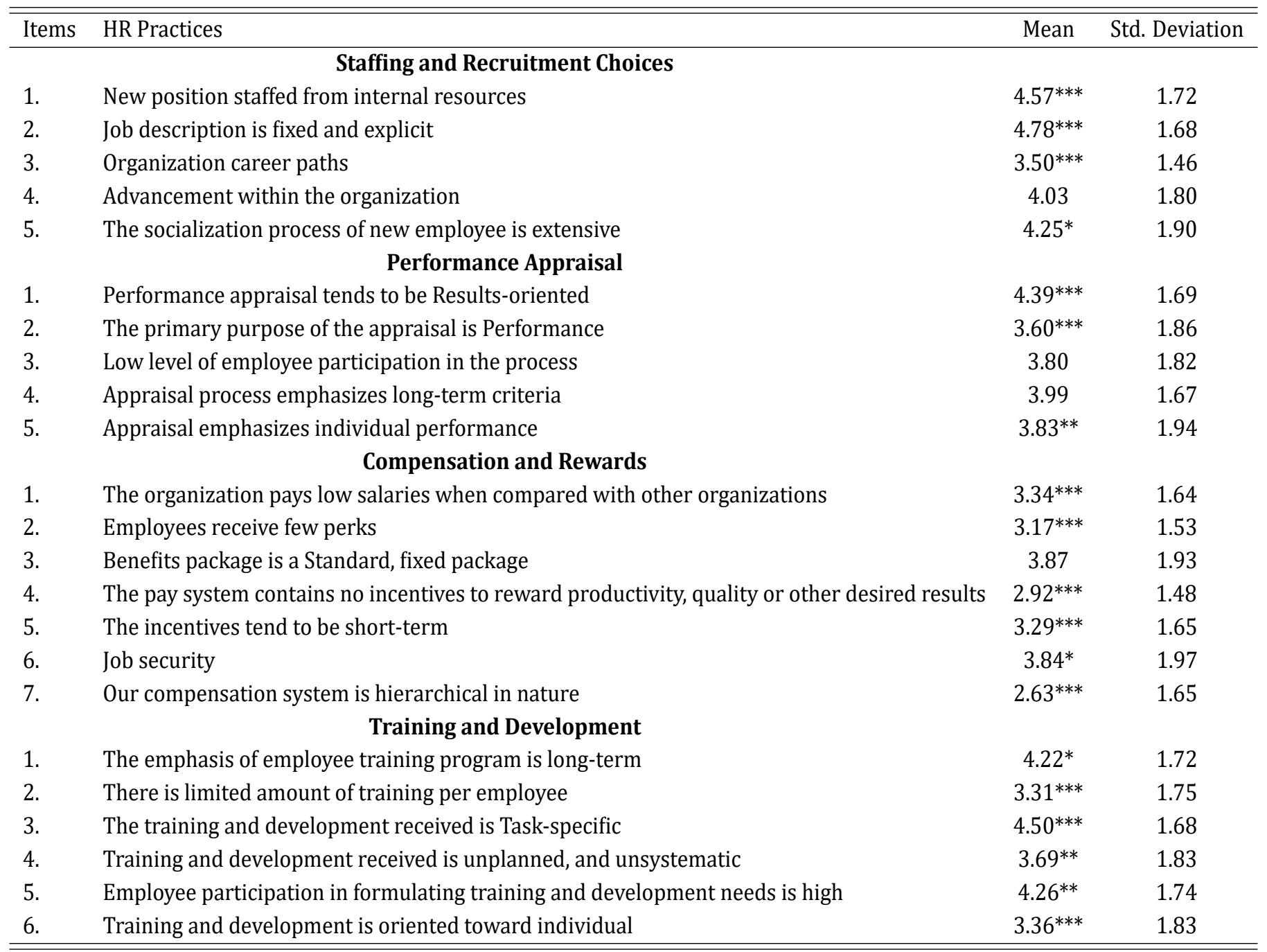

${ }^{*}$ Statistically significant at .05 level, ${ }^{* *}$ statistically significant at .01 level, ${ }^{* * *}$ statistically significant at .001 level 
For the attitude measures, as shown in table (2), respondents are very committed to the organization with Mean score of 4.76, but less satisfied with Mean $=4.36$. How ever, respondents demonstrate very low intention to leave the Agency with Mean $=2.68$. Results also show that they are motivated with score 5.15 (based on a 7-point scale). The results show that the relationships are in the anticipated directions. Two dependent variables - commitment and sat- isfaction - have the strongest association with the four bundles of HPWS practices. The strongest association reported between training and development, performance appraisal, and rewards and recognition. Finally, it is clear that the aggregate effects of HPWS have the highest association with each of the dependent variables. This also indicates that HPWS are mutually reinforcing, overlapping, and have synergistic effect on employee attitudes.

TABLE 2 . Means, standard deviations and t test of difference between mean and mid-point

\begin{tabular}{lcccc}
\hline \hline Items & $\mathrm{N}$ & Mean & Std. Deviation & Cronbach's Alpha \\
\hline Organizational Commitment (Cronbach alpha .85) & 231 & $4.76^{* * *}$ & 1.01 & 0.85 \\
Job Satisfaction (Cronbach alpha .92) & 233 & $4.36^{* * *}$ & 1.09 & 0.92 \\
Motivation (Cronbach alpha .75) & 229 & $5.15^{* * *}$ & 0.51 & 0.65 \\
Intention to Quit & 224 & $2.68^{* * *}$ & 1.91 & -- \\
\hline \hline
\end{tabular}

TABLE 3 . Means, standard deviations and t test of difference between mean and mid-point

\begin{tabular}{|c|c|c|c|c|c|c|c|c|c|c|}
\hline & & 1 & 2 & 3 & 4 & 5 & 6 & 7 & 8 & 9 \\
\hline \multirow[t]{3}{*}{ 1.Commitment } & Spearman's rho & 1.000 & & & & & & & & \\
\hline & Sig. (1-tailed) & . & & & & & & & & \\
\hline & $\mathrm{N}$ & 231 & & & & & & & & \\
\hline \multirow[t]{3}{*}{ 2.Satisfaction } & Spearman's rho & $.740^{* *}$ & 1.000 & & & & & & & \\
\hline & Sig. (1-tailed) & .000 & . & & & & & & & \\
\hline & $\mathrm{N}$ & 231 & 233 & & & & & & & \\
\hline \multirow[t]{3}{*}{ 3.Motivation } & Spearman's rho & $.258^{* *}$ & $.273^{* *}$ & 1.000 & & & & & & \\
\hline & Sig. (1-tailed) & .000 & .000 & . & & & & & & \\
\hline & $\mathrm{N}$ & 229 & 229 & 229 & & & & & & \\
\hline \multirow[t]{3}{*}{ 4.Intention to Quit } & Spearman's rho & $-.488^{* *}$ & $-.356^{* *}$ & $-.168^{* *}$ & 1.000 & & & & & \\
\hline & Sig. (1-tailed) & .000 & .000 & .006 & . & & & & & \\
\hline & $\mathrm{N}$ & 224 & 224 & 223 & 224 & & & & & \\
\hline \multirow[t]{3}{*}{ 5.Staffing and Recruitment } & Spearman's rho & $.229^{* *}$ & $.361^{* *}$ & $.127^{*}$ & -.102 & 1.000 & & & & \\
\hline & Sig. (1-tailed) & .000 & .000 & .028 & .064 & . & & & & \\
\hline & $\mathrm{N}$ & 231 & 233229 & 224 & 234 & & & & & \\
\hline \multirow[t]{3}{*}{ 6.Performance Appraisal } & Spearman's rho & $.454^{* *}$ & $.569^{* *}$ & .051 & $-.263^{* *}$ & $.408^{* *}$ & 1.000 & & & \\
\hline & Sig. (1-tailed) & .000 & .000 & .221 & .000 & .000 & . & & & \\
\hline & $\mathrm{N}$ & 231 & 233 & 229 & 224 & 233 & 233 & & & \\
\hline \multirow[t]{3}{*}{ 7.Compensation and Rewards } & Spearman's rho & $.313^{* *}$ & $.506^{* *}$ & $.196^{* *}$ & $-.133^{*}$ & $.297^{*}$ & $.383^{* *}$ & 1.000 & & \\
\hline & Sig. (1-tailed) & .000 & .000 & .001 & .024 & .000 & .000 & 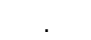 & & \\
\hline & $\mathrm{N}$ & 231 & 233 & 229 & 224 & 233 & 233 & 233 & & \\
\hline \multirow[t]{3}{*}{ 8.Training and Development } & Spearman's rho & $.469 * *$ & $.600^{* *}$ & $.197^{* *}$ & $-.248^{* *}$ & $.324^{* *}$ & $.398^{* *}$ & $.627^{* *}$ & 1.000 & \\
\hline & Sig. (1-tailed) & .000 & .000 & .001 & .000 & .000 & .000 & .000 & . & \\
\hline & $\mathrm{N}$ & 230 & 231 & 228 & 223 & 231 & 231 & 231 & 231 & \\
\hline \multirow[t]{3}{*}{ 9.HPWS Spearman's rho } & $.506^{* *}$ & $.683^{* *}$ & $.193^{* *}$ & $-.247^{* *}$ & $.608^{* *}$ & $.674^{* *}$ & $.783^{* *}$ & $.823^{* *}$ & 1.000 & \\
\hline & Sig. (1-tailed) & .000 & .000 & .002 & .000 & .000 & .000 & .000 & .000 & \\
\hline & $\mathrm{N}$ & 231233 & 229 & 224 & 234 & 233 & 233 & 231 & 234 & \\
\hline
\end{tabular}

The bivariate relationships between the dependent and independent variables are outlined in table 3. Results show that the highest association is between training and development and job satisfaction with $\mathrm{rs}=0.600$ significant at $(\rho$ $<0.01$ ). Job satisfaction has also relatively strong association with performance appraisal with $\mathrm{rs}=0.569$ significant at $(\rho<0.01)$. Finally, there is moderate association between job satisfaction and selection and recruitment practices with $r s=0.361$ significant at $(\rho<0.01)$. For employee com- mitment, the results indicate that employee commitment has strongest association with the same independent variable (training and development) with $r s=0.469$ significant at $(\rho<0.01)$. The association between employee commitment and selection and recruitment practices is the lowest compared to other practices with $\mathrm{rs}=0.361$ significant at $(\rho$ $<0.01$ ). However, there is significant correlation between motivation and the other bundles of HPWS practices. For instance positive correlation exists between training and 
development and motivation with positive Spearman correlation of $r s=0.197$ significant at $(\rho<0.01)$. The following section will now consider the relative impact of the independent variables on individual worker outcomes through ordinary least squares multiple linear regression analyses.

\section{OLS Regression Analyses}

The four hypotheses identified were tested using hierarchal multiple regression in an attempt to estimate the net effect of each of the independent variables (bundles of HPWS practices) on the dependent variables (employee attitude). Four models are presented in table (4) below, combining the independent variables to predict the dependent variable. Based on the regression equations, results reveal that each of the independent variables significantly contributes to explanation in variance in one or more of the attitude measures. Detailed presentation of each of the four models associated with the four dependent variables is discussed below.

TABLE 4. Means and standard deviations

\begin{tabular}{|c|c|c|c|c|c|c|c|c|}
\hline \multirow{3}{*}{ Predictors } & \multicolumn{6}{|c|}{ Individual outcomes } & \multirow{2}{*}{\multicolumn{2}{|c|}{ Model 4: Intention to Qui }} \\
\hline & \multicolumn{2}{|c|}{ Model 1: Commitment } & \multicolumn{2}{|c|}{ Model 2: Satisfaction } & \multicolumn{2}{|c|}{ Model 3: Motivation } & & \\
\hline & $\boldsymbol{\beta}$ & (t) & $\beta$ & (t) & $\boldsymbol{\beta}$ & (t) & $\boldsymbol{\beta}$ & (t) \\
\hline Staffing and Recruitment & -0.010 & -0.168 & .060 & 1.144 & .065 & .936 & -.007 & -.100 \\
\hline Compensation and Rewards & -0.036 & -0.514 & $.204^{* *}$ & 3.082 & $.103^{* *}$ & 3.061 & .088 & 1.064 \\
\hline Training and Development & $.305^{* * *}$ & 5.719 & $.324^{* * *}$ & 5.471 & .098 & 1.201 & $-.349^{* *}$ & -3.121 \\
\hline $\mathrm{N}$ & \multicolumn{2}{|c|}{229} & \multicolumn{2}{|l|}{230} & \multicolumn{2}{|c|}{227} & \multicolumn{2}{|c|}{222} \\
\hline
\end{tabular}

${ }^{*}$ Statistically significant at .05 level, ${ }^{* *}$ statistically significant at .01 level, ${ }^{* * *}$ statistically significant at .001 level

As shown in table (4), the first model shows that two bundles of HPWS are powerful and statistically significant predictors of employee commitment. This indicates that both performance appraisal and training and development have positive effects on employee commitment. For this dependent variable, adjusted R2 $=0.319$, which shows that the model accounts for $31.9 \%$ of variance in employee commitment significant at $(\rho<0.001)$. Accordingly, both bundles: performance appraisal $(\beta=0.309, \rho<.001)$, and training and development $(\beta=.305, \rho<.001)$ are statistically significant predictors of employee commitment. The model also reveals that neither rewards and compensation, nor recruitment bundles are statistically significant predictors of employee commitment.

Consistent with previous research on the relationship between training provision and employee commitment, training provision leads to improvements in organizational commitment based on the social exchange theory (Bartlett, 2001; Al-Emadi \& Marquardt, 2007). Social exchange theory posits that employees enter into a relationship with the organization so as to maximize the benefits they obtain (Blau, 1964). Researchers argue that employees' training provision is part of the unwritten psychological contract between the organization and employees (Newman, Thanacoody, \& Hui, 2011).
Employees perceive training and development opportunities in exchange for displayed organizational commitment (Bartlett, 2001). Similarly, for performance appraisal, previous research has shown that performance appraisal process is characterized with employee participation in setting of goals and standards for performance, which also increase chances of employee commitment (Vasset, Marnburg,\& Furunes, 2011). In addition, performance appraisal helps organization in clarifying employee roles and reduces any ambiguities, which also leads to higher levels of commitment (Pettijohn, Pettijohn \& Taylor, 2001). The direction of the relationships was anticipated for two of the four bundles of HPWS practices; the exception being staffing and recruitment, where there is no significant effect from the regression analysis. However, the agreement among HRM scholars is that staffing and recruitment selection procedures have positive effects on employee commitment (Bowen \& Ostroff, 2004, Dyer \& Reda, 2010). This result may reflect respondents' experience of limited opportunities within the organization for other positions and promotions. One of the interviewees stated that "promotion opportunities within the organization are very limited". However, this is perceived from senior management as more flexible recruitment system that allows for external hiring which allows the organization to select the best candidates. 
One Chief program officer indicated that One of the main objectives of selection process is to find the candidate who has the appropriate knowledge, skills, and abilities to perform well on the job from a pool of applicants for a position. We cannot assume that everyone who works for the organization and apply for a job is qualified to actually perform it. Therefore, now we can hire externals if we are not able to find the internal qualified person for the job. This situation illustrates the need for workers to understand management's motives for recruitment and staffing activities. Failure to do so is likely to undermine the anticipated effects of flexible and comprehensive selection processes. The second model shows that three bundles of HPWS practices are statistically significant predictors of employee's job satisfaction. These bundles are performance appraisal, compensation and rewards, and training and development and each of these bundles have positive effects on employee's job satisfaction. For this model, adjusted R2 $=0.493$, which indicates that the model accounts for $49.3 \%$ of variance in job satisfaction measures significant at $(\rho<0.001)$. Three bundles of HPWS practices are powerful and statistically significant predictors of job satisfaction: performance appraisal $(\beta=.357, \rho<.001)$, compensation and rewards $(\beta=$ $.204, \rho<.01)$, and training and development $(\beta=.324, \rho<$ $.001)$.

Accordingly, there is an indication of statistically significant effects of three bundles of HPWS practices on employee job satisfaction in IGOs. Results are consistent with previous studies on the effects of performance appraisal on employees' job satisfaction. Many studies have shown positive significant relationship between job satisfaction and compensation (Beutell \& Wittig-Berman, 1999), training and development (Jones, Jones, Latreille \& Sloane, 2009), and performance appraisal (Pettijohn et al., 2001). For instance, studies have shown that performance appraisal process establishes feedback system between employees and their managers which permits for managers to clearly define subordinates' roles within the workplace. The resulted feedback minimizes role ambiguity among employees in different types of organizations which, in turn, negatively correlates with job satisfaction. Finally, the second model also reveals that staffing and recruitment is not statistically significant predictor of employee satisfaction and has no statistically significant effects on employee satisfaction. As shown in the third model, only one of the four HPWSs is statistically significant predictor of employee motivation. The results of the regression analysis reveal that none of the individual bundles of HPWS practices is powerful pre- dictor for motivation and intention to quit. For employee motivation dependent variable, adjusted R2 $=0.040$, which indicates very little effects of the independent variables on employee motivation. These effects account only for $4.0 \%$ of the variance in employee motivation significant at $\rho<$ 0.01 . Only compensation and rewards $(\beta=.103, \rho<.01)$ is statistically significant predictor of employee motivation and has positive statistically significant relationship with employee motivation. The model also reveals staffing and recruitment, performance appraisal, and training provision are not statistically significant predictors of employee motivation. Accordingly, there is an indication of positive impacts of only one bundle of HPWS practices on employee motivation in IGOs. This could be referred to as what has been referred as Public Service Motivation (PSM), proposed by James Perry and Lois Recascino Wise in published essay "The Motivational Bases of Public Service". The authors proposed that motivation among public servants originates from unique motives and beliefs that are different from those of their private sector counterparts (Perry and Wise, 1990). The authors defined PSM as "an individual's predisposition to respond to motives grounded primarily or uniquely in public institutions and organizations" (1990, p. 368).

The definition clearly emphasizes motives, such as civic duty and compassion that are commonly associated with public organizations. Finally, the fourth model shows that only one of the four bundles of HPWS is statistically significant predictor of employee's intention to quit. For employee intention to quit dependent variable, adjusted R2 $=0.042$, which indicates that the model accounts only for $4.2 \%$ of variance in employee's intention to quit significant at $\rho<$ 0.01 . Accordingly, there is a very little effect of only one bundle of HPWS, namely training and development bundle that has statistically significant relationship with $(\beta=$ -.103, $\rho<.01$ ) on employee's intention to quit. Therefore, results indicate that training and development is the only statistically significant predictor of this dependent variable with inverse relationship. The model also reveals that the other three bundles of HPWS practices including staffing and recruitment, performance appraisal, and compensation and rewards are not statistically significant predictors of employee's intention to quit. Accordingly, there is an indication of inverse relationship with negative impacts of only one bundle of HPWS practices on employee's intention to quit in IGOs. The majority of research addressing what factors impact employee's intention to quit suggests that stress resulting from workloads and the relationships 
between supervisors and subordinates are major causes for employees' intention to leave the organization (Firth, Mellor, Moore, \& Loquet, 2004). However, some previous research addressing intention to quit among employees suggests that specific training, which focuses on building employees' skills related to the job, makes employees reluctant to quit their jobs as workers believe that the benefits of training are lost if they leave to another organization (Sieben, 2007).

\section{CONCLUSION AND IMPLICATIONS}

This paper aimed at evaluating the effects of bundles of HPWS practices on IGOs' worker attitudes. The study evaluates four employee attitude measures, namely commitment, job satisfaction, motivation and intention to quit. The results were based on employee questionnaire and face-toface interviews collected from a cross-section of employees working in humanitarian IGO with quasi-governmental role providing education, health, infrastructure, relief and social services. As such, this paper has contributed to the current HRM-Performance debate by extending the analysis to IGOs. The findings reported here are consistent with previous research demonstrating a link between bundles of HPWS practices and enhanced worker attitudes (Guest, 2001; Paawue, 2009). Of the four bundles of HPWS practices used in this study, only training and development had a consistent effect on three measures of employee attitudes. Training and development has positive relationship with employee commitment, and satisfaction, and inverse relationship with employee's intention to quit.

Results have also shown that performance appraisal has strong positive relationship with employee commitment and satisfaction. On the other hand, compensation and rewards have positive relationship with employee satisfaction and motivation. Managers working in IGOs need to consider enhancing employee attitudes with increased focus on training and development activities along with ensuring that adequate consideration is given to incentives and pay structure. Findings demonstrate that HPWS is perceived differently by the individual workers which may contribute to explaining the different effects of HPWS in IGO context. Additionally, previous research within HRM literature emphasized that country differences and contextual factors may also impact the perceptions of individual workers towards HPWS especially in IGO's context (Fey et al., 2000).One of the main conclusions of this study relates to employees' perception towards the application of HPWS and the effectiveness of adopting HPWS. The study results demonstrate that out of 23 practices identified as HPWS practices, only seven practices have been identified to be adopted by the organization based on employees' perception. This indicates that there are different perceptions among IGOs' employees with regards to the organization of HRM reform. This brings one of the main issues within HRM literature which refers to the fit between HRM practices, policies, and processes addressing the actual deployment of HRM systems and whether HRM policies match HRM practices and business processes. Previous research has shown that for HPWS to be effective, policies should match both the actual HRM practices and processes applied within the organization. Misfit between the policy and the practice could result into ineffective or counterproductive effects on employees' attitude (Kepes \& Delery, 2007). Employees' attitudes and behaviors are affected by processes more than policies so when policies and processes are not aligned, employees may demonstrate negative behaviors due to perceptions of injustice (Simons \& Roberson, 2003). The results obtained from face-to-face interviews validated the results obtained from the closed-end questionnaire revealing that most employees did not feel that the policies and procedures are particularly effective. Most employees confided that they perceived real intention for major changes in HRM policies and practices. The employees indicated that increased recognition, empowerment and open communication have positively influenced workers' attitudes.

However, they believe that the organization did little to attempt to implement additional and more tangible changes in other areas such as internal promotion, new pay system, and training and development programs. The implication is that there should be considerations towards employees' perceptions of HRM practices to avoid any contradictions between the intended HRM policies and actual HRM practices experienced by employees. Previous research examining employees' perception towards HRM practices showed that while managers describe the performance evaluation process as an open discussion between employees and management, employees felt that employee-goals were set without consulting them (Kooij, Jansen, Dikkers, \& De Lange, 2010). In a similar study, better communication between management and staff involving them in decision-making activities was perceived as information overload from staff leading to negative individual outcomes (Gould-Williams, 2004). Therefore, individual work-related HRM outcomes are affected by employees' perceptions of HRM practices, instead of by intended HRM policies (Edgar 
\& Geare, 2005; Guest, 2002). In the same line of reasoning, there are some implications related to the process of developing, implementing and administering the adopted HPWS. Researchers argue that the possession of certain practices is not a sufficient condition but is a necessary condition for attaining the desired HRM outcomes (Khilji \& Wang, 2006). Gerhart (2005) it is very important for organization adopting HPWS to consider how to develop, implement and administer HPWS practices to achieve high level of HRM outcomes on the organizational level (Gerhart, Wright, Mahan, \& Snell, 2000). Results demonstrated variation in employees' perception towards implemented bundles of HPWS practices. These results were validated from interview participants who reported that the organization clearly announced new austerity measures which affected the deployment of HPWS especially with implementing new pay system. For instance, results indicate that the organization failed to sustain internal or external equity, provide incentives for quality of work and provide lots of benefits for employees. Previous research on international compensation has shown that the unique nature of multinational enterprises including IGOs which rely on donors for its operations, face funding challenges when it comes to compensation and rewards system (O'Sullivan, 2010). In many cases, donor countries' budgets vary in terms of salaries and in the exchange rates upon which salaries are to be calculated.

Therefore, within the IGO context, salaries may vary according to the donor's country funding which may influence the internal compensation equity. On the other hand, external equity is also a challenge due to the complexity of determining suitable market rates and possible lack of HRM expertise in using of salary surveys to determine the appropriate salary levels (Festing, Eidems, \& Royer, 2007). Finally, HPWSs are complementary systems with synergistic effects when combined into coherent HRM architecture. Appropriate compensation and rewards practices would enhance the effectiveness of staffing and recruitment practices because compensation and rewards practices often serve to attract and maintain talented individuals who possess the highest levels of skills. The linking of compensation and rewards to performance appraisal and to feedback systems would also enhance the effectiveness of training and development, because dialogue between managers and employees can inform employees about requisite skills and knowledge identifying employees' capacity building needs. The implication seems to be that because of the austerity measures implemented within the organization, funding restriction on organization plans had consolidated impacts on other areas of the HRM reform process. Thus it may be important to consider the other organizational factors and resources and to further plan the reform process. Further research is needed to determine whether staffing and recruitment strategies affect employees' attitude in public organization.As with any study of this kind, the following limitations need to be considered when evaluating study findings. One of the limitations of this study comes from the nature of cross section research design which is common in HRM literature and has been previously discussed from several academics. According to Paauwe (2004), the cross-sectional data used in research examining the effects of HPWS on employees did not permit any tests of the causal ordering between the effects of HPWS and performance. While the study results specify the effects of HPWS on employee attitudes, testing the causal relationship with performance outcomes requires longitudinal research approach which involves repeated observations of the same variables over long periods of time. However, data collection on management issues over long time period is difficult and expensive especially with traditional survey methods (Paauwe, 2004). Another limitation for this study is that only single organization was included in this study due to the lack of researcher resources.

Therefore, study findings are limited to the research site and study participants. Although similarities may exist between the findings in this study and other IGOs, caution should be taken in making generalizations about the findings of this study in relation to other comparable institutions. However, limiting research to single organization assisted in isolating HPWS in an attempt to control size, age, and technology besides other possible interdependencies for the effects of HPWS on the organizational level. Finally, in real life there are many independent variables that may affect employee attitudes in addition to HRM practices. These variables may include work relationships, organizational politics and organizational leadership (Allen Tammy \& Eby, 2012; Walumbwa, Hartnell, \& Oke, 2010; Chang, Rosen, \& Levy, 2009). However, this study was limited to examining HPWS practices as independent variables. Any other variables that may affect the dependent variables were excluded from the study. Nevertheless, despite these limitations, the results presented here suggest that the bundles of HPWS practices have positive effects on employees' attitude in IGO context and this supports similarities with other types of organizations. 


\section{REFERENCES}

Al-Emadi, M.A.S., \& Marquardt, M.J. 2007. Relationship between employees' beliefs regarding training benefits and employ- ees' organizational commitment in a petroleum company in the State of Qatar. International Journal of Training \& Development, 11(1): 49-70. DOI: 10.1111/j.1468-2419.2007.00269.x

Allen Tammy D., \& L.T.T.Eby. 2012. The study of interpersonal relationships: An introduction, personal relationships.

The effect on employee attitudes, behavior, and well-being. New York, NY: Routledge Appelbaum, E., Bailey, T., Berg, P., \& Kalleberg, A. 2000. Manufacturing advantage: Why high-performance work systems pay off. Ithaca, NY: Cornell University Press.

Bartlett, K.R. 2001. The relationship between training and organizational commitment: A study in the health care field. Hu- man Resource Development Quarterly, 12(4): 335-352. D0I: 10.1002/hrdq.1001

Beadles, I.I., Aston, N., Lowery, C.M., \& Johns, K. 2015. The impact of human resource information systems: An exploratory study in the public sector. Communications of the IIMA, 5(4): 39-46.

Beaupré, D., \& Cloutier, J. 2007. La gestion à «haute performance» dans la fonction publique québécoise: Pratiques mobilisatrices et cohérence. Relations Industrielles/Industrial Relations, 62(3): 516-539. D0I: 10.7202/016491ar

Becker, B.E., \& Huselid, M.A. 2006. Strategic human resources management: Where do we go from here? Journal of Management, 32(6): 898-925. DOI: 10.1177/0149206306293668

Beutell, N.J., \& Wittig-Berman, U. 1999. Predictors of work-family conflict and satisfaction with family, job, career, and life.

Psychological Reports, 85(3): 893-903. DOI: 10.2466/pr0.1999.85.3.893

Blau, P. M. 1964. Exchange and power in social life. URL : goo.gl/iGOME. Last accessed on 5 September 2016.

Boselie, P., Dietz, G., \& Boon, C. 2005. Commonalities and contradictions in HRM and performance research. Human Re- $\quad$ source Management Journal, 15(3): 67-94. D0I: 10.1111/j.1748-8583.2005.tb00154.x

Bowen, D.E., \& Ostroff, C. 2004. Understanding HRM-firm performance linkages: The role of the "strength" of the HRM sys- $\quad$ tem. Academy of Management Review, 29(2): 203-221. DOI: 10.2307/20159029

Boxall, P. , Ang, S.H., \& Bartram, T. 2011. Analysing the 'black box' of HRM: Uncovering HR goals, mediators, and outcomes in a standardized service environment. Journal of Management Studies, 48(7): 1504-1532.

DOI: $10.1111 / \mathrm{j} .1467-6486.2010 .00973 . x$

Boxall, P. 2012. High-performance work systems: What, why, how and for whom? Asia Pacific Journal of Human Re- sources, 50(2): 169-186. DOI: 10.1111/j.1744-7941.2011.00012.x

Boyne, G.A. 2002. Public and private management: What's the difference? Journal of Management Studies, 39(1): 97-122. DOI: $10.1111 / 1467-6486.00284$

Brown, K. 2004. Human resource management in the public sector. Public Management Review, 6(3): 303-309. DOI: $10.1080 / 1471903042000256501$

Cafferkey, K., \& Dundon, T. 2015. Explaining the black box: HPWS and organisational climate. Personnel Review, 44(5): 666-688. DOI: 10.1108/PR-12-2012-0209

Chang, C.H., Rosen, C.C., \& Levy, P.E. 2009. The relationship between perceptions of organizational politics and employee attitudes, strain, and behavior: A meta-analytic examination. Academy of Management Journal, 52(4): 779-801.

DOI: $10.5465 /$ AMJ.2009.43670894

Colley, L., McCourt, W., \& Waterhouse, J. 2012. Hybrids and contradictions: Human resource management in the contempopublic sector. International Journal of Public Administration, 35(8): 507-512.

DOI: $10.1080 / 01900692.2012 .687958$

Daley, D.M., \& Vasu, M.L. 2005. Supervisory perceptions of the impact of public sector personnel practices on the achievement of multiple goals putting the strategic into human resource management. The American Review of Public Administration, 35(2): 157-167. DOI: 10.1177/0275074004272846

Datta, D.K., Guthrie, J.P., \& Wright, P. M. 2005. Human resource management and labor productivity: does industry matter? Academy of Management Journal, 48(1): 135-145. DOI: /10.5465/AMJ.2005.15993158

Dyer, L., \& Reda, B. 2010. Making sense of selection: Reactions to HR practices in small organizations. Entrepreneurial Practice Review, 1(2): 4-12. 
Edgar, F., \& Geare, A. 2005. HRM practice and employee attitudes: Different measures-different results. Personnel Re- view, 34(5): 534-549. DOI: 10.1108/00483480510612503

Festing, M., Eidems, J., \& Royer, S. 2007. Strategic issues and local constraints in transnational compensation strategies:

An analysis of cultural, institutional and political influences. European Management Journal, $25(2): 118-131$.

DOI: $10.1016 /$ j.emj.2007.01.001

Fey, C.F., Björkman, I., \& Pavlovskaya, A. 2000. The effect of human resource management practices on firm performance in

Russia. International Journal of Human Resource Management, 11(1): 1-18. D0I: 10.1080/095851900339963

Firth, L., Mellor, D.J., Moore, K.A., \& Loquet, C. 2004. How can managers reduce employee intention to quit? Journal of Man- agerial Psychology, 19(2): 170-187. DOI: 10.1108/02683940410526127

Gerhart, B. 2005. Human resources and business performance: Findings, unanswered questions, and an alternative ap- proach. Management Revue, 16(2): 174-185.

Gerhart, B., Wright, P. M., MAHAN, G.C., \& Snell, S.A. 2000. Measurement error in research on human resources and firm performance: How much error is there and how does it influence effect size estimates? Personnel Psychology, 53(4): 803-834.

DOI: $10.1111 /$ j.1744-6570.2000.tb02418.x

Gould-Williams, J. 2004. The effects of 'high commitment' HRM practices on employee attitude: The views of public sector workers. Public Administration, 82(1): 63-81. D0I: 10.1111/j.0033-3298.2004.00383.x

Guest, D.E. 2001. Human resource management: When research confronts theory. International Journal of Human Re-

Management, 12(7): 1092-1106. DOI: 10.1080/09585190110067837

Guest, D. 2002. Human resource management, corporate performance and employee wellbeing: Building the worker into HRM. Journal of Industrial Relations, 44(3): 335-358. DOI: 10.1111/1472-9296.00053

Guthrie, J.P. 2001. High-involvement work practices, turnover, and productivity: Evidence from New Zealand. Academy of Management Journal, 44(1): 180-190. DOI: 10.2307/3069345

Huselid, M.A. 1995. The impact of human resource management practices on turnover, productivity, and corporate financial performance. Academy of Management Journal, 38(3): 635-672. D0I: 10.2307/256741

Ingvaldsen, J.S. Johansen, T., \& Aarlott, M. 2014. Emergent HPWS: why HRM may not be needed to build a high-performance work system. Team Performance Management, 20(7/8): 294-306. DOI: 10.1108/TPM-03-2014-0021

Jones, M.K., Jones, R.J., Latreille, P. L., \& Sloane, P.J. 2009. Training, job satisfaction, and workplace performance in Britain: Evidence from WERS 2004. Labour, 23(s1): 139-175. DOI: 10.1111/j.1467-9914.2008.00434.x

Kalleberg, A.L., Marsden, P. V., Reynolds, J., \& Knoke, D. 2006. Beyond profit? Sectoral differences in high-performance work practices. Work \& Occupations, 33(3): 271-302. DOI: 10.1177/0730888406290049

Katou, A.A., \& Budhwar, P.S. 2007. The effect of human resource management policies on organizational performance in Greek manufacturing firms. Thunderbird International Business Review, 49(1): 1-35. D0I: 10.1002/tie.20129 Kepes, S., \& Delery, J.E. 2007. HRM systems and the problem of internal fit. New York, NY: Oxford University Press. Khilji, S.E., \& Wang, X. 2006. Intended and implemented HRM: The missing linchpin in strategic human resource manage- ment research. The International Journal of Human Resource Management, 17(7): 1171-1189.

DOI: $10.1080 / 09585190600756384$

Kooij, D.T., Jansen, P. G., Dikkers, J.S., \& De Lange, A.H. 2010. The influence of age on the associations between HR practices and both affective commitment and job satisfaction: A meta-analysis. Journal of Organizational Behavior, 31(8):

1111- 1136. DOI: $10.1002 /$ job.666

Leggat, S.G., Bartram, T. , \& Stanton, P. 2011. High performance work systems: The gap between policy and practice in health care reform. Journal of Health Organization \& Management, 25(3): 281-297. D0I: 10.1108/14777261111143536 Lindner, J.R. 1998. Understanding employee motivation. Journal of Extension, 36(3): 1-8.

MacDuffie, J.P. 1995. Human resource bundles and manufacturing performance: Organizational logic and flexible produc- $\quad$ tion systems in the world auto industry. Industrial \& Labor Relations Review, 48(2): 197-221. D0I: 10.2307/2524483

Macky, K., \& Boxall, P. 2007. The relationship between 'high-performance work practices' and employee attitudes: An inves- $\quad$ tigation of additive and interaction effects. The International Journal of Human Resource Management, 18(4): 537- 567. DOI: 10.1080/09585190601178745 
Mahdi, S.M., Liao, J., Muhammad, S., \& Nader, H.M. 2014. The Impact of high performance work system (HPWS) on employee productivity as related to organizational identity and job engagement. European Journal of Business \& Management, 6(39): 1-24.

Mostafa, A.M.S., \& Gould-Williams, J.S. 2014. Testing the mediation effect of person-organization fit on the relationship be- tween high performance HR practices and employee outcomes in the Egyptian public sector. The International Journal of Human Resource Management, 25(2): 276-292. DOI: 10.1080/09585192.2013.826917

Newman, A., Thanacoody, R., \& Hui, W. 2011. The impact of employee perceptions of training on organizational commitment and turnover intentions: A study of multinationals in the Chinese service sector. The International Journal of Human Resource Management, 22(8): 1765-1787. DOI: 10.1080/09585192.2011.565667

O'Sullivan, S.L. 2010. International human resource management challenges in Canadian development INGOs. European Management Journal, 28(6): 421-440. DOI: 10.1016/j.emj.2010.06.006

Paauwe, J. 2004. HRM and performance: Achieving long-term viability. NweYork, NY: Oxford University Press. DOI: 10.1093/acprof:oso/9780199273904.001.0001

Paauwe, J. 2009. HRM and performance: Achievements, methodological issues and prospects. Journal of Management Studies, 46(1): 129-142. DOI: 10.1111/j.1467-6486.2008.00809.x

Payne, S.C., Horner, M.T., Boswell, W.R., Schroeder, A.N., \& Stine-Cheyne, K.J. 2009. Comparison of online and traditional performance appraisal systems. Journal of Managerial Psychology, 24(6): 526-544. D0I: 10.1108/02683940910974116 Perry, J.L., \& Wise, L.R. 1990. The motivational bases of public service. Public Administration Review, 50(3): 367-373. DOI: $\quad 10.2307 / 976618$

Pettijohn, C., Pettijohn, L.S., Taylor, A.J., \& Keillor, B.D. 2001. Are performance appraisals a bureaucratic exercise or can they be used to enhance sales-force satisfaction and commitment? Psychology \& Marketing, 18(4): 337-364.

DOI: $10.1002 /$ mar. 1011

Porter, L.W., Steers, R.M., Mowday, R.T., \& Boulian, P.V. 1974. Organizational commitment, job satisfaction, and turnover among psychiatric technicians. Journal of Applied Psychology, 59(5): 603-615. DOI: 10.1037/h0037335

Rainey, H.G., \& Bozeman, B. 2000. Comparing public and private organizations: Empirical research and the power of the a priori. Journal of Public Administration Research and Theory, 10(2): 447-470.

DOI: 10.1093/oxfordjournals.jpart.a024276

Sackmann, S.A., Phillips, M.E., Kleinberg, M.J., \& Boyacigiller, N.A. 1997. Single and multiple cultures in international crosscultural management research: Overview. Cultural Complexity in Organizations, 4(5): 14-48.

Schroeder, R. 1992. Max Weber and the sociology of culture. London, UK: Sage Publications.

Sieben, I. 2007. Does training trigger turnover-or not? The impact of formal training on graduates' job search behaviour. Work, Employment \& Society, 21(3): 397-416. DOI: 10.1177/0950017007080004

Simons, T., \& Roberson, Q. 2003. Why managers should care about fairness: The effects of aggregate justice perceptions on organizational outcomes. Journal of Applied Psychology, 88(3): 432-433. D0I: 10.1037/0021-9010.88.3.432

Skaggs, B.C., \& Youndt, M. 2004. Strategic positioning, human capital, and performance in service organizations: A customer interaction approach. Strategic Management Journal, 25(1): 85-99. DOI: 10.1002/smj.365

Sourchi, S.M., \& Liao, J. 2015. The positive impact of high performance work systems (HPWS) on employee commitment and self-sufficiency in strategic human resource management (SHRM) in Kurdistan. European Journal of Business \& Manage- ment, 7(3): 80-109.

Sparrow, P., \& Wu, P.C. 1998. Does national culture really matter? Predicting HRM preferences of Taiwanese employees.

Employee Relations, 20(1): 26-56. DOI: 10.1108/01425459810369823

Spector, P. E. 1997. Job satisfaction: Application, assessment, causes, and consequences. New York, NY: SAGE Publica- $\quad$ tions

Stanton, P., \& Manning, K. 2013. High performance work systems, performance management and employee participation in the public. Human Resource Management in the Public Sector, 13(1): 255-269.

Schuler, R.S., \& Jackson, S.E. 1987. Linking competitive strategies with human resource management practices. The Academy of Management Executive, 3(6): 207-219. DOI: 10.5465/AME.1987.4275740

Teo, S.T., \& Crawford, J. 2005. Indicators of strategic HRM effectiveness: A case study of an Australian public sector agency 
during commercialization. Public Personnel Management, 34(1): 1-16. DOI: 10.1177/009102600503400101

UNRWA. 2006a. UNRWA's rganizational development plan 2006-09: Serving Palestine refugees more effectively: Strengthening the management capacity of UNRWA. Working paper United Nations Relief and Works Agency, Amman, JO. UNRWA. 2006b. Human resources management (HRM) strategy, serving Palestine refugees with qualified, competent and motivated staff. Working paper United Nations Relief and Works Agency, Amman, JO.

Vasset, F., Marnburg, E., \& Furunes, T. 2011. The effects of performance appraisal in the Norwegian municipal health ser- $\quad$ vices: A case study. Human Resources for Health, 9(1): 1-12. DOI: 10.1186/1478-4491-9-22

Walumbwa, F. O., Hartnell, C.A., \& Oke, A. 2010. Servant leadership, procedural justice climate, service climate, employee attitudes, and organizational citizenship behavior: A cross-level investigation. Journal of Applied Psychology, 95(3): 517-529. DOI: $10.1037 / \mathrm{a} 0018867$

Wood, S. 1999. Human resource management and performance. International Journal of Management Reviews, 1(4): 367-413. DOI: 10.1111/1468-2370.00020

Zhang, M., Zhu, C.J., Dowling, P.J., \& Bartram, T. 2013. Exploring the effects of high-performance work systems (HPWS) on the work-related well-being of Chinese hospital employees. The International Journal of Human Resource Manage24(16): 3196-3212. DOI: 10.1080/09585192.2013.775026

— This article does not have any appendix. - 